\title{
直交異方性積層板上に作用する点衝撃荷重の荷重履歴簡便同定方法*1 A Simple Method for Identifying Force Histories of Point Impact Forces on Orthotropic Laminated Plates
}

\author{
関 根 英 樹*2・佐 藤 正 喜*2・小 野 㠃 徹*2 \\ Hideki Sekine, Masaki Sato and Tohru OnOZAKI
}

Key Words : Composite Material, Orthotropic Laminated Plate, Identification, Point Impact Force, Force History

\begin{abstract}
The inverse technique has been developed for the problem of force histories identification of point impact forces on orthotropic laminated plates. In a previous paper, the authors presented a simple method for identification of multiple impact forces acting on simply supported orthotropic laminated plates. The method utilized measured values of acceleration to predict point impact forces which resulted in the laminated plate response. This paper describes an attempt to extend the method to clamped orthotropic laminated plates and identify force histories of point impact forces. In addition, this paper explores an iterative method to identify accurately force histories using a reduced number of measurement points. Several numerical examples are performed to ascertain effectiveness of the method to clamped laminated plates, the effect of the number of measurement points on the identification results for boundary conditions and validity of the iterative method.
\end{abstract}

\section{1. 緒言}

先進複合材料は高比強度・高比剛性の点に㧍いて非常に 優れた性質を有することから, 厳しい軽量化が要求される 航空宇宙機の構造材料としてその適用が㹡大しつつある. 航空宇宙機の主構造材の一つである複合材料積層板は，面 外方向からの衝撃荷重に対して弱く，鳥や宇宙デブリなど 異物の衝突によって層間はく離などの損傷を受ける可能性 がある。このような状況下で，航空宇宙機の運用中の安全 性を確保するためには， 八ルスモニタリングの概念による 機体に対する健全性の監視が重要となる．また，機体の健 全性の監視を迅速に行うためには，衝撃荷重の履歴放よび 衝撃荷重が作用した位置に関する情報を実時間で得ること が極めて重要である。

点衝撃荷重を対象とした荷重同定に関する従来の研究と しては, 逆解析手法を用いて, 等方性はりや等方性板およ

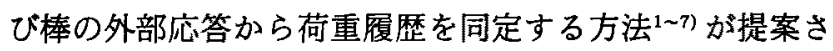
れている。また，等方性板に作用する 1 点衝撃荷重を対象 に, 荷重履歴や荷重の大きさのみでなく荷重位置の同定を も行った研究8 10)も報告されている。さらに，文献 11)に 扔いては, 直交異方性積層板上の複数点に作用する衝撃荷 重の荷重位置・履歴を，加速度情報より実時間で簡易に同 定する方法が提案されている。そこでは，積層板が単純支 持された場合に限定しており，提案した同定方法の他の支 持条件に対する有效性については検討していない。 また， 同定方法の実用性を考虑すれば，計測点数は少ない方が望

\footnotetext{
${ }^{* 1}$ 平成 11 年 8 月 31 日原稿受理

${ }^{* 2}$ 東北大学大学院工学研究科航空宇宙工学専攻
}

ましいが，少ない計測点数の場合には，同定精度は保証さ れていない.

そこで，本研究では，前報11で周辺単純支持直交異方 性皘層板に限定していた点衝撃荷重の簡易同定法を，周辺 固定支持直交異方性積層板に対しても適用できるように拡 張した。周辺単純支持および周辺固定支持直交異方性積層 板上の複数点に作用する衙撃荷重の荷重履歴同定の数值計 算例を通して，本同定方法の周辺固定支持積層板に対する 有効性，扔よび各境界条件に扔いて計測点数が同定精度に 及ほす影響について検討した。また，計測点数を減少させ た場合に生じる同定誤差を反復計算により補正し，少ない 計測点数で精度良い同定結果を得る方法についても検討し た。

\section{2. 点衝擊荷重の荷重履歴同定式および反復法}

2.1 同定基礎式 直交異方性積層板と $x, y$ 座標系を 第 1 図に示す。ここでは，積層板上の $N$ 個の任意点に衝 撃荷重を受ける場合の応答を考える，ただし，衝撃荷重は 点衝撃荷重であるとする，古典積層理論を用いると，積層 板の運動方程式は次式で与えられる。

$$
\begin{aligned}
& D_{11} \frac{\partial^{4} w}{\partial x^{4}}+2\left(D_{12}+2 D_{66}\right) \frac{\partial^{4} w}{\partial x^{2} \partial y^{2}}+D_{22} \frac{\partial^{4} w}{\partial y^{4}}+\rho h \frac{\partial^{2} w}{\partial t^{2}} \\
& \quad=\sum_{n=1}^{N} f_{n}(t) \delta\left(x-x_{n}\right) \delta\left(y-y_{n}\right)
\end{aligned}
$$

ここで, $D_{i j}$ は面外剛性, $w$ はたわみ， $\rho$ は板の密度， $h$ は板厚, $t$ は時間を示す.また, $f_{n}(t)$ および $\left(x_{n}, y_{n}\right)$ 的第 $n$ 番目の点衝撃荷重の荷重履歷および荷重位置を示し, $\delta(x)$ はデル夕関数を示す. 


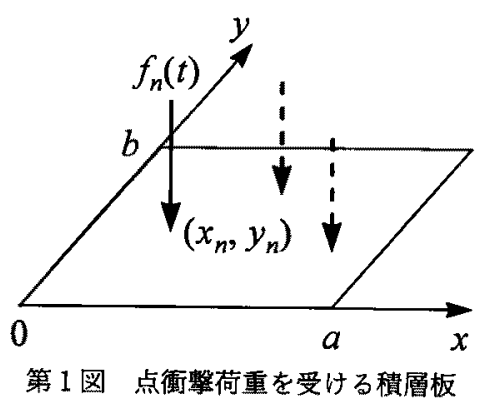

境界条件は周辺単純支持と周辺固定支持の二とおりにつ いて考えるものとし，おのおの次式で与えられる.

(i) 周辺単純支持の場合

$$
\begin{aligned}
& x=0, \quad a: w=D_{11} \frac{\partial^{2} w}{\partial x^{2}}+D_{12} \frac{\partial^{2} w}{\partial y^{2}}=0 \\
& y=0, \quad b: w=D_{12} \frac{\partial^{2} w}{\partial x^{2}}+D_{22} \frac{\partial^{2} w}{\partial y^{2}}=0
\end{aligned}
$$

(ii）周辺固定支持の場合

$$
\begin{aligned}
& x=0, \quad a: w=\frac{\partial w}{\partial x}=0 \\
& y=0, \quad b: w=\frac{\partial w}{\partial y}=0
\end{aligned}
$$

次に, $X=x / a, Y=y / b$ と無次元化して, 各境界条件に 対する積層板の固有振動モード $g_{i j}(X, Y)$ を次式で仮定す る.

$$
\begin{aligned}
& \text { (i) 周辺単純支持の場合 } \\
& g_{i j}(X, Y)=\sin (i \pi X) \sin (j \pi Y)
\end{aligned}
$$

(ii) 周辺固定支持の場合

$$
\begin{aligned}
g_{i j}(X, Y)= & \sum_{k=1}^{K} \sum_{l=1}^{L} \phi_{k i}^{i j}[\cos \{(k-1) \pi X\} \\
& -\cos \{(k+1) \pi X\}] \\
& \times[\cos \{(l-1) \pi Y\}-\cos \{(l+1) \pi Y\}]
\end{aligned}
$$

ただし，式(5)における $\phi_{k l}^{i j}$ は，積層板の自由振動解析に おける $i j$ 次の固有モードベクトルを示す.

仮定した固有振動モードは，それぞれ境界条件を満足す ることを考慮して, たわみを固有振動モードの線形関数と して次式のように表す。

$$
W(X, Y, t)=\sum_{i=1}^{t} \sum_{j=1}^{f} \bar{W}_{i j}(t) g_{i j}(X, Y)
$$

ここに

$$
W(X, Y, t)=\frac{w(X, Y, t)}{h}, \quad \bar{W}_{i j}(t)=\frac{\bar{w}_{i j}(t)}{h}
$$

得られたたわみを積層板の運動方程式に代入し， $\omega_{i j}$ を 積層板の固有角振動数とすると，次式が得られる．

$$
\sum_{n=1}^{N} F_{n}(t) g_{i j}\left(\xi_{n}, \eta_{n}\right)=A_{i j}(t)
$$

ここで,

$$
\begin{gathered}
\xi_{n}=\frac{x_{n}}{a}, \quad \eta_{n}=\frac{y_{n}}{b}, \quad F_{n}(t)=\frac{4 f_{n}(t)}{\rho h^{2} a b} \\
A_{i j}(t)=4 \int_{0}^{1} \int_{0}^{1}\left(\frac{\mathrm{d}^{2} W(X, Y, t)}{\mathrm{d} t^{2}}\right. \\
\left.+\omega_{i j}{ }^{2} W(X, Y, t)\right) g_{i j}(X, Y) \mathrm{d} X \mathrm{~d} Y
\end{gathered}
$$

式（8) は, 時刻 $t$ における点衝撃荷重の荷重位置・荷重履

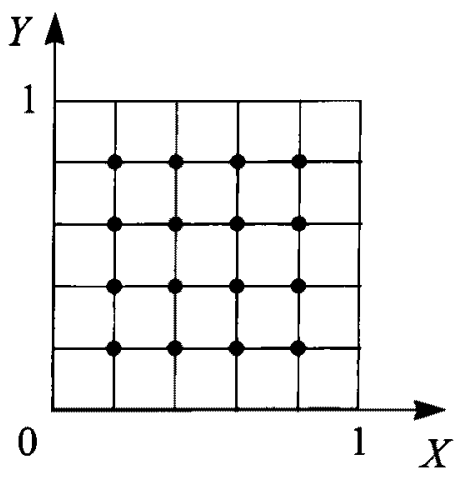

第 2 図 加速度計測点数

歴と積層板のたわみ・加速度の間に成立する関係であり 点衝撃荷重の同定における基礎式となる。また，式(8) は，いずれの境界条件に扔いても成立するため，周辺固定 支持の場合においても，点衝撃荷重の簡易同定法は適用可 能であることがわかる。

式(10)の $A_{i j}(t)$ は加速度・たわみ情報から決定される 值であるが，たわみ情報は加速度情報を積分すれば求める ことができるため，計測情報としては加速度のみで十分で ある.ここでは，第 2 図に示すように，無次元化した $X$, $Y$ 座標の区間 $l$ に等分割された格子点での積層板の加速 度を計測するものとする。計測点数は板内部の格子点総数 の $(l-1)^{2}$ であり，積層板の周辺での加速度は零とする． 第 2 図の例では， $l=5$ で計測点数は 16 点である. 各計測 点における加速度の計測情報をもとに台形公式による数値 積分を行い $A_{i j}(t)$ を求める.

2.2 点衝擊荷重の荷重履歴同定式 積層板上の複数点 に作用する衝撃荷重の荷重位置が既知である場合につい て，荷重履歴を求めることを考える。

一般に，積層板上の $N$ 点に衝撃荷重が作用する場合， 同定すべき未知数は荷重夏歷 $F_{1}(t), \cdots, F_{N}(t) の N$ 個であ る. 式 (8)の同定基礎式を用いると $F_{1}(t), \cdots, F_{N}(t)$ を求 める問題は，次式で示される $N$ 元連立 1 次方程式を解く 問題に帰着する。

$$
\begin{gathered}
\left\{\begin{array}{c}
F_{1}(t) g_{11}\left(\xi_{1}, \eta_{1}\right)+\cdots+F_{N}(t) g_{11}\left(\xi_{N}, \eta_{N}\right)=A_{11}(t) \\
F_{1}(t) g_{12}\left(\xi_{1}, \eta_{1}\right)+\cdots+F_{N}(t) g_{12}\left(\xi_{N}, \eta_{N}\right)=A_{12}(t) \\
\quad \vdots \\
F_{1}(t) g_{p q-1}\left(\xi_{1}, \eta_{1}\right)+\cdots+F_{N}(t) g_{p q-1}\left(\xi_{N}, \eta_{N}\right)=A_{p q-1}(t) \\
F_{1}(t) g_{p q}\left(\xi_{1}, \eta_{1}\right)+\cdots+F_{N}(t) g_{p q}\left(\xi_{N}, \eta_{N}\right)=A_{p q}(t)
\end{array}\right. \\
\quad(\text { ただし, } \quad p \times q=N)
\end{gathered}
$$

例えば，積層板上の任意の 1 点に衝撃荷重が作用する場 合，荷重履歴 $F_{1}(t)$ は次式で求められる。

$$
F_{1}(t)=\frac{A_{11}(t)}{g_{11}\left(\xi_{1}, \eta_{1}\right)}
$$

また，積層板上の任意の 2 点に衝撃荷重が作用する場 合，次式により $F_{1}(t), F_{2}(t)$ が求められる.

$$
\left[\begin{array}{l}
F_{1}(t) \\
F_{2}(t)
\end{array}\right]=\left[\begin{array}{ll}
g_{11}\left(\xi_{1}, \eta_{1}\right) & g_{11}\left(\xi_{2}, \eta_{2}\right) \\
g_{12}\left(\xi_{1}, \eta_{1}\right) & g_{12}\left(\xi_{2}, \eta_{2}\right)
\end{array}\right]^{-1}\left[\begin{array}{l}
A_{11}(t) \\
A_{12}(t)
\end{array}\right]
$$

2.3 少ない計測点の場合における同定精度改善方法 前報で提案した点衝撃荷重の簡易同定法 ${ }^{11}$ において，精 
度良い同定を行うためには式(10)の $A_{i j}(t)$ を正確に求め なくてはならない，そのためには，極めて数多くの計測点 での加速度情報を用いて数值積分詥差を排除しなければな らないが，実用性を考慮すると，できるだけ少ない計測情 報から同定を行う必要がある. 文献 12)において注, 静荷 重負荷時のたわみ計測情報を用いた積層板の曲げ岡性同定 に反復法を適用することにより，少ないたわみ計測点数の 場合においても精度良い同定が可能となることが報告され ている。

本研究では，荷重履歴同定に対して反復法を用いること により，計測点数減少に起因する同定誤差を補正すること を試みる。

第 3 図に反復法のフローチャートを示す．まず，計測さ れた加速度 $\ddot{w}(t)$ より $A_{i j}(t)$ を計算し, 荷重履歷 $f_{n}(t)$ を 同定する. 得られた $f_{n}(t)$ は式(10)の数值積分による誤差 を含んでいる。この $f_{n}(t)$ を用いて積層板の応答解析を行 い,たわみ $\tilde{w}(t) \cdot$ 加速度 $\tilde{\tilde{w}}(t)$ を計算する。計測された 加速度 $\ddot{w}(t)$ と応答解析による加速度 $\tilde{\ddot{w}}(t)$, および計測 された加速度を積分することで得たたわみ $w(t)$ と応答解 析によるたわみ $\widetilde{w}(t)$ の差をそれぞれ $\Delta \ddot{w}(t), \Delta w(t)$ とし， 式(10)に代入すると $\Delta A_{i j}(t)$ が計算できる. 先ほどの $A_{i j}(t)$ とこの $\Delta A_{i j}(t) の$ 和 $\left(A_{i j}(t)+\Delta A_{i j}(t)\right)$ を新たに

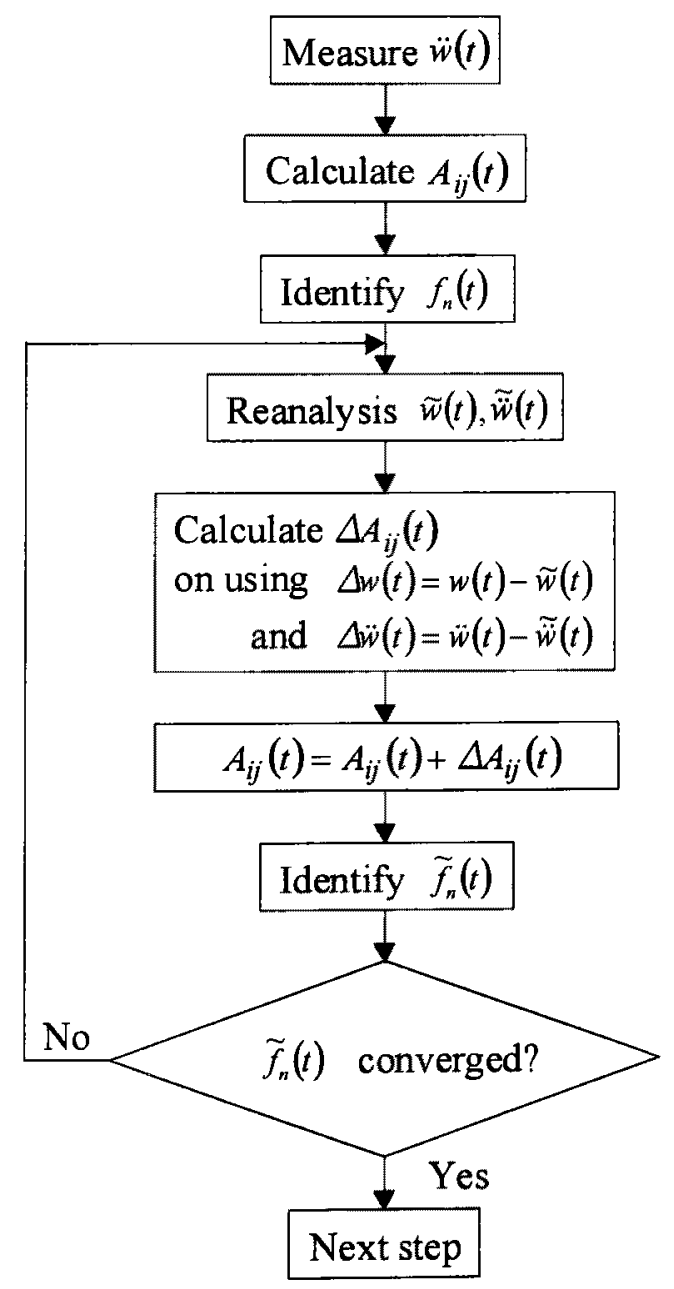

第 3 図 反復法のフローチャート
$A_{i j}(t)$ と置き直し,この新たな $A_{i j}(t)$ を用いて再度, 荷 重履歴 $\tilde{f}_{n}(t)$ の同定を行う。このように, 同定された荷重 履歴が収束するまで反復計算を行い，同定誤差を補正す る。

同定された荷重履歴の収束判定には次式を用いる。

$$
\left|\frac{\tilde{f}_{n}^{m}(t)-\tilde{f}_{n}^{m-1}(t)}{\tilde{f}_{n}^{m}(t)}\right|<\varepsilon
$$

ここで, $\tilde{f}_{n}^{m}(t)$ は $m$ 回目の反復計算において同定された 荷重履歴である。ただし， $\tilde{f}_{n}^{0}(t)=f_{n}(t)$ とする。

\section{3. 数值計算結果および考察}

本同定方法によって同定された荷重履歷の同定精度評価 指標として，次式で定義される $\Delta f_{n}(t)$ を用いる。

$$
\Delta f_{n}(t)=\frac{\left|f_{n}^{\text {exact }}(t)-f_{n}(t)\right|}{f_{n}^{\text {exact }}(t)} \times 100[\%]
$$

ここで, $f_{n}^{\text {exact }}(t)$ は $n$ 番目の点衝撃荷重に対する正解の 荷重履歴を示す。同定精度評価の際には正解の荷重負荷開 始時刻から負荷終了時刻までの $\Delta f_{n}(t)$ の平均值, $\Delta f_{n}^{\text {ave }}$ で評価するものとする。

数值計算例としては，炭素繊維/エポキシ樹脂複合材料 を考え, 積層構成 $\left[0_{2} / 90\right]_{\mathrm{s}}$ の直交異方性積畨板を対象にす る.計算に用いた一方向材の材料定数および積層板の具体 的寸法を第 1 表に示す。ここで， $E_{\mathrm{L}}$ ：瀻維方向のヤング 率， $E_{\mathrm{T}}$ : 繊維と重直方向のヤング率， $G_{\mathrm{T}}$ : せん断係数, 次：緎維方向のポアソン比である。

積㞗板の自由振動解析において, 自由振動の固有振動飞 一ドが式 (4)で与えられる周辺単純支持の場合は正解の固 有角振動数が得られる.一方, 自由振動の固有振動モード が式 ( 5 )で与えられる周辺固定支持の場合は固有角振動数 の収束を考慮し， $K \times L=7 \times 7$ を用いた。

積層板の応答解析における式 (6)の項数としては, 周辺 単純支持および周辺固定支持のいずれの場合でも，高周波 の影響を除去するものと仮定してたわみの収束性のみを考 慮し， $I \times J=7 \times 7$ を用いた。また, 積層板の初期条件と して荷重負荷前はたわみ・加速度ともに零で静止している ものとする。

与える点衝撃荷重に関しては，点衝撃荷重を半波の正弦 パルスで仮定し，第 2 表に示す 2 種類の荷重を考えた。

3.1 点衝撃荷重の荷重履歴同定 周辺単純支持あるい は周辺固定支持の直交異方性積層板を対象とし，点衝撃荷 重の荷重位置が既知の場合について，荷重履歷の同定を行 う.

\section{第 1 表 材料定数}

$E_{\mathrm{L}}=142[\mathrm{GPa}], \quad E_{\mathrm{T}}=10.8[\mathrm{GPa}], G_{\mathrm{LT}}=5.49[\mathrm{GPa}]$,
$\nu_{\mathrm{L}}=0.3, \rho=1,600\left[\mathrm{~kg} / \mathrm{m}^{3}\right]$
$a=100[\mathrm{~mm}], \quad b=100[\mathrm{~mm}], h=1[\mathrm{~mm}]$

第 2 表 点衝撃荷重

\begin{tabular}{cccc}
\hline $\begin{array}{c}\text { Force number: } \\
n\end{array}$ & $\begin{array}{c}\text { Loading point } \\
\left(\xi_{n}^{\text {exact }}, \eta_{n}^{\text {exact }}\right)\end{array}$ & Max. load $[N]$ & Period $[\mathrm{ms}]$ \\
\hline 1 & $(0.6,0.4)$ & 1,000 & 0.4 \\
2 & $(0.3,0.7)$ & 750 & 0.3 \\
\hline
\end{tabular}




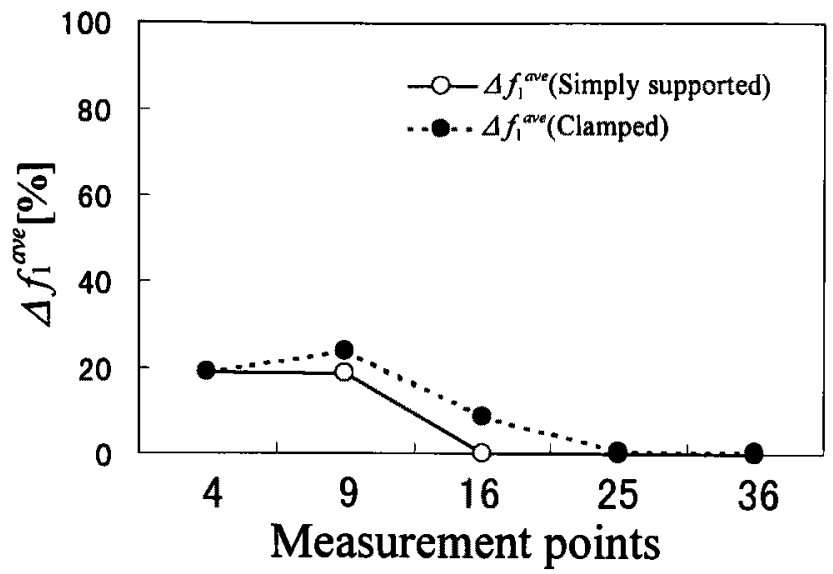

第 4 図 計測点数が荷重履歷の同定精度に及ほす影響（1 点衝 撃荷重)

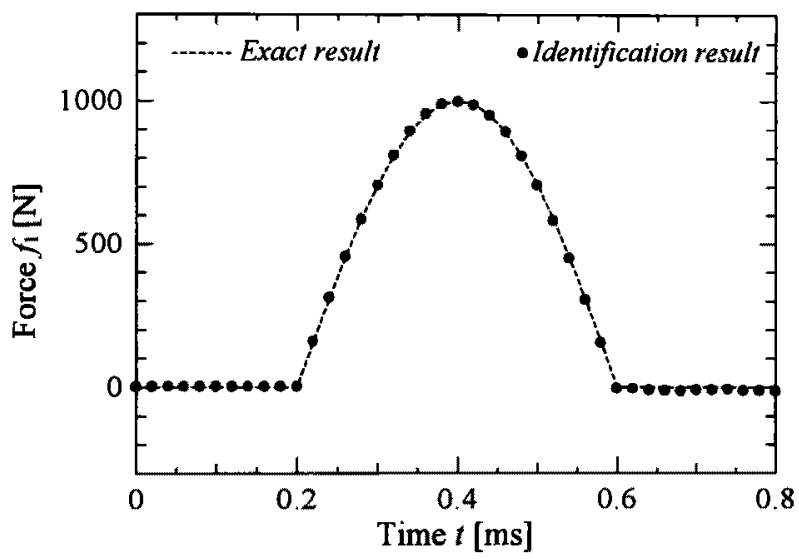

第 5 図 1 点衝撃荷重の荷重履歴同定結果（周辺固定支持, 計 測点数：25 点)

ただし，各計測点での加速度は $20 \mu \mathrm{s}$ 毎に計測誤差なく 計测できるものとし，得られた $A_{i j}(t)$ を用いて $\Delta T=20$ $\mu \mathrm{S}$ 毎に同定を行う.

3.1 .11 点衝撃荷重 ここでは, 1 点衝撃荷重の場合に ついての荷重履歴同定を行った。

（i）周辺単純支持の場合*3：第 4 図における実線に， 周辺単純支持において, 加速度計測点数が荷重履歴の同定 精度に及ぼす影響を示す。ここでは，計測点数を 4 点， 9 点, 16 点, 25 点および 36 点と変化させた場合について, 同定精度評価指標 $\Delta f_{1}^{\text {ave }}$ を示した．周辺単純支持の場合に おいて, 本数值計算例での 1 点衝撃荷重の荷重履憷を精度 良く同定するためには，16 点の計測点数が最低限必要で あることがわかる。

（ii）周辺固定支持の場合：第 4 図に扔ける点線に，周 辺固定支持において, 加速度計測点数が荷重履歴の同定精 度に及ぼす影響を示す，周辺固定支持の場合において，本 数值計算例での 1 点衝撃荷重の荷重履歷を精度良く同定す るためには，25 点の計測点数が最低限必要であることが わかる。ここで，第 5 図に，周辺固定支持の場合の， 25

${ }^{* 3}$ 文献 11)では，直交異方性積層板を対象として，点衝擊荷重の 荷重位置と荷重履歷を同時に同定する場合について取り报った ものであり，正解の荷重位置が同定された場合に対応する。
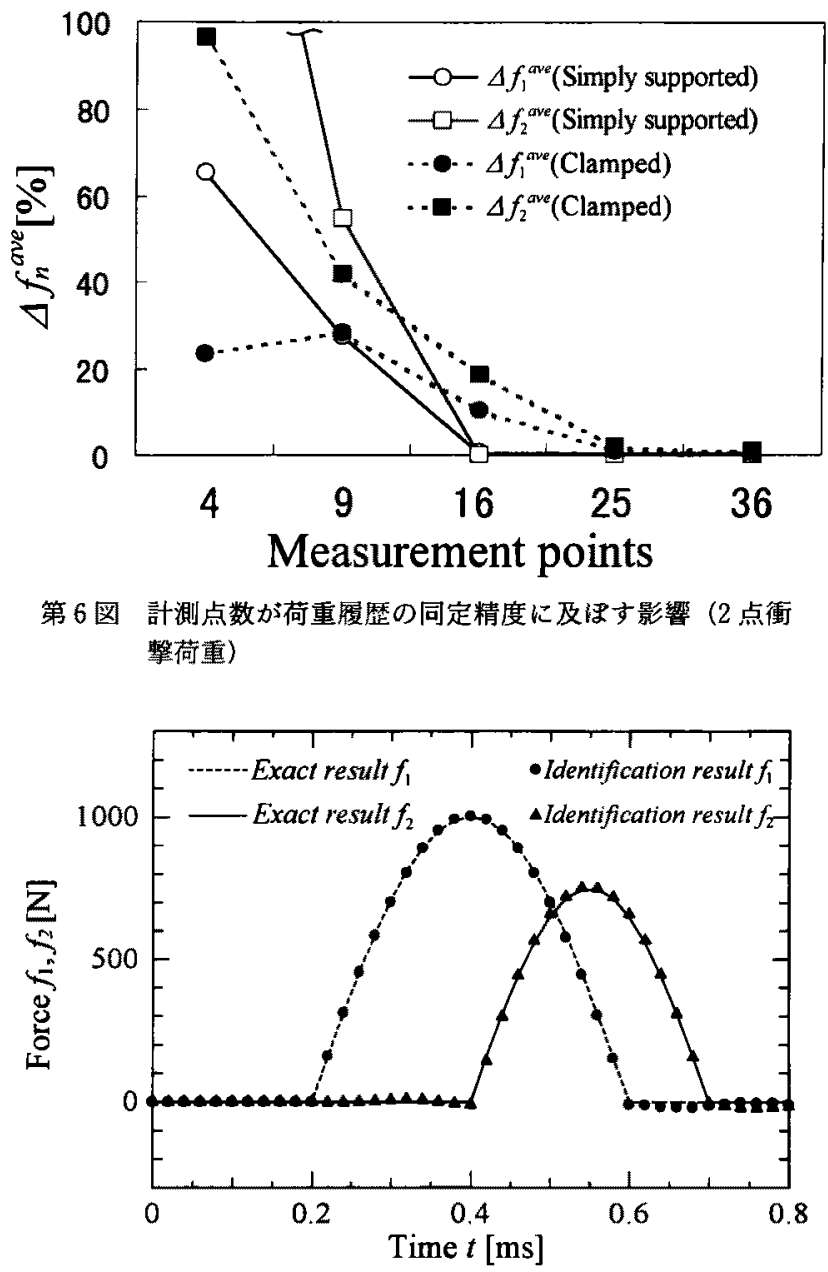

第 7 图 2 点衝擊荷重の荷重履歴同定結果（周辺固定支持，計 測点数 : 25 点)

点計測における荷重履歴の同定結果を示す。同定された荷 重履歴と正解の荷重履歴は一致して扔り，周辺固定支持の 場合において良好な同定結果が得られていることがわか る.

3.1 .22 点衝撃荷重 ここでは，2 点衝撃荷重の場合に ついての荷重履歴同定を行った。

（i）周辺単純支持の場合：第 6 図における実線に，周 辺単純支持において, 加速度計測点数が荷重履歴の同定精

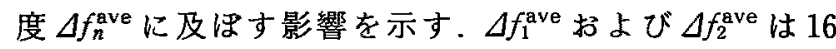
点以上の計測点数でほ涩零に収束している。このことから 1 点衝撃荷重の場合と同様に，16 点の計測点数を用いれ ば, 2 点衝撃荷重における荷重 1 , 荷重 2 は十分精度良く 同定できることがわかる．

（ii）周辺固定支持の場合：第 6 図における点線に，周 辺固定支持において，加速度計測点数が荷重履歴の同定精 度 $\Delta f_{n}^{\mathrm{ave}}$ に及ほす影響を示す．周辺固定支持の場合におい て 25 点の計測点数を用いれば，1点衝撃荷重の場合と同 様に，2 点衝撃荷重の場合も十分精度良く同定できること がわかる。ここで，第 7 図には，周辺固定支持の場合の， 25 点計測における荷重履歴の同定結果を示す．同定され た荷重履歴と正解の荷重履歷は, 荷重 1 , 荷重 2 ともにほ ぼ一致しており，いずれの荷重履歴も高精度に同定されて 


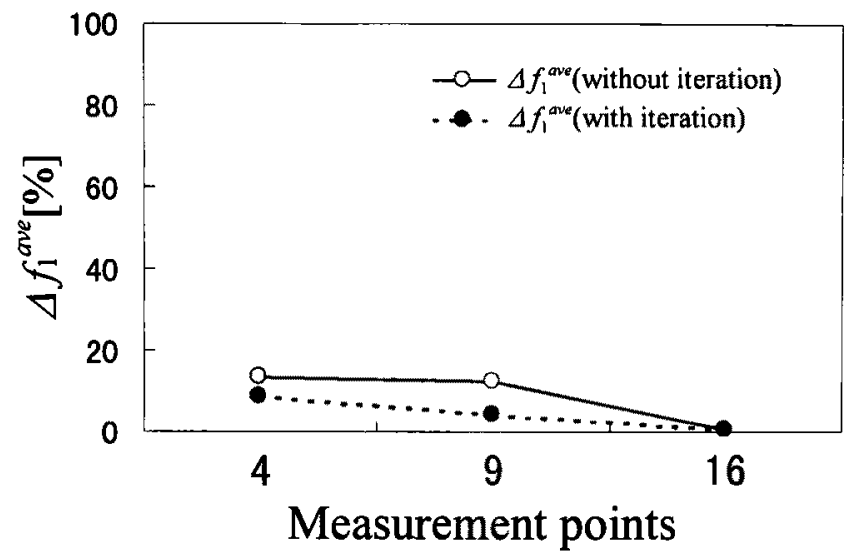

第 8 図＼cjkstart隇少させた計測点数が荷重履歴の同定精度に及沽す影 響（1 点衝揧荷重, 周辺単純支持)

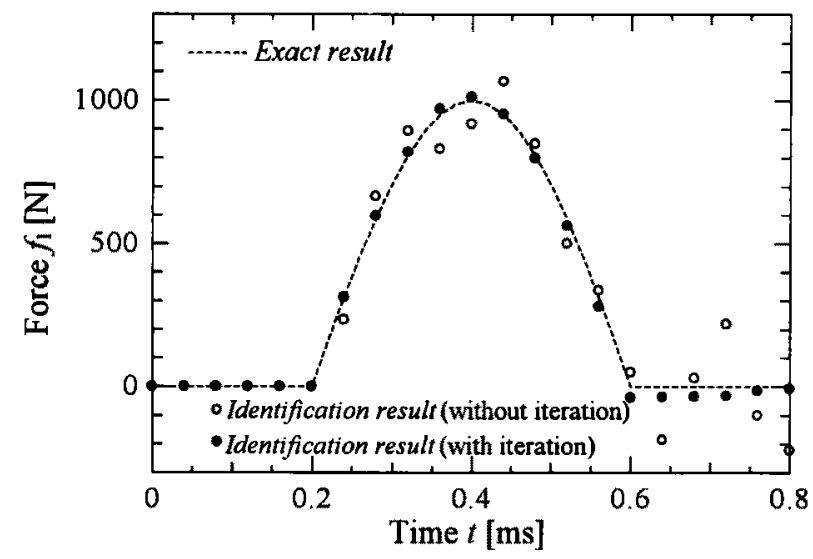

第 9 図 1 点衝撃荷重の荷重履歴同定結果（周辺単純支持，計 測点数 $: 9$ 点)

いることがわかる。

以上より，本同定方法は周辺固定支持積層板にも適用可 能であることがわかった．また，荷重履歴を精度良く同定 するために必要な加速度計測点数は，境界条件によって異 なることがわかった．本研究で対象とした 1 点，2点衝撃 荷重の荷重履歴を精度良く同定するためには，周辺単純支 持の場合は 16 点, 周辺固定支持の場合は 25 点の計測点数 が最低限要求される．境界条件によって精度良い同定に必 要な計測点数に差があるのは, 各境界条件で固有角振動数 が異なることが理由の一つとして考えられる。すなわち， 積層板の固有角振動数が大きいほど，各計測点の時間に対 する挙動変化が大きくなり，式（8）の同定基礎式における $A_{i j}(t)$ を精度良く近似するためには，より多くの計測点数 が必要になるということである．このため，周辺単純支持 積層板よりも固有角振動数の大きくなる周辺固定支持積層 板を対象とした場合は，精度良い同定のために，より多く の計測点数が要求されると考えられる.

\section{2 計測点数を減少させた場合の点衝擊荷重の荷重履} 歴同定 周辺単純支持あるいは周辺固定支持の直交異方 性積層板を対象とし, 点衝撃荷重の荷重位置が既知の場合 について, 加速度計測点数を減少させて荷重履歴の同定を 行う.

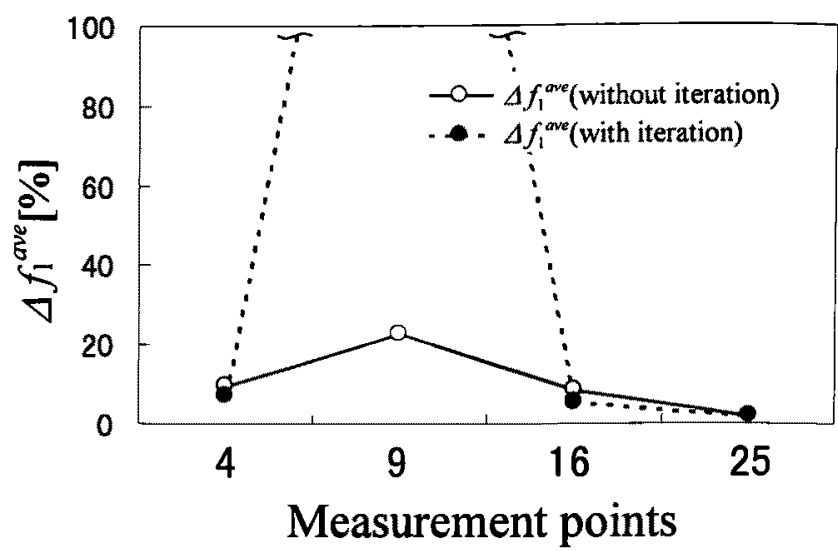

第 10 図 減少させた計測点数が荷重履歴の同定精度に及涩す 影響（1 点衝擊荷重，周辺固定支持）

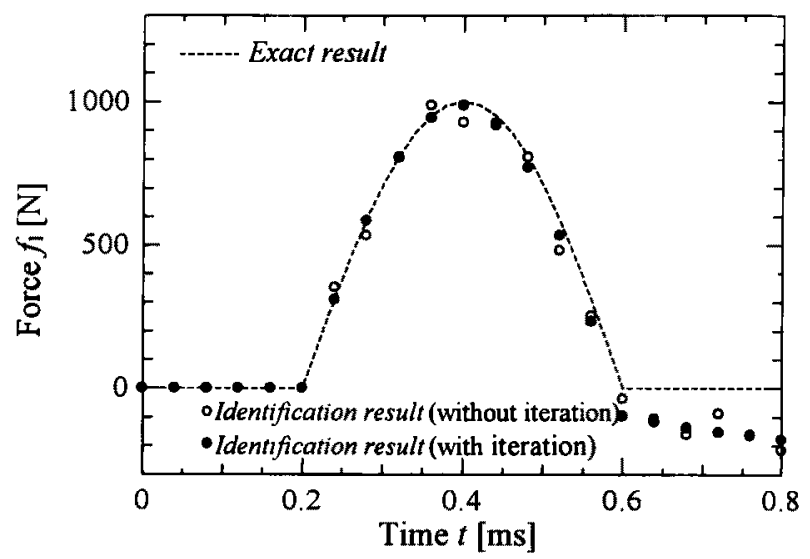

第11図1点衝擊荷重の荷重履歴同定結果（周辺固定支持， 計測点数 : 16 点)

ただし，計測点数に関しては，3 章 1 節における数値計 算結果より，周辺単純支持で 16 点，周辺固定支持で 25 点 の計測点数が最低限必要であることがわかっている．従っ て，周辺単純支持では 16 点以下，周辺固定支持では 25 点 以下の計測点数に対して数值計算を行うものとする．その 際は，同定に反復法を用いない場合および反復法を用いた 場合の同定結果の比較から反復法の有効性を検証する.

また，反復法を用いた場合は計算時間が増加する可能性 があるため，ここでは各計測点での加速度が $40 \mu \mathrm{s}$ 毎に計 測誤差なく計測できるものとし，得られた $A_{i j}(t)$ を用い て $\Delta T=40 \mu \mathrm{s}$ 毎に同定を行うものとした，さらに，式 (14)における $\varepsilon$ は， $\varepsilon=0.05$ とした.

3.2 .11 点衝撃荷重 ここでは，1点衝撃荷重の場合に ついて荷重履歴同定を行った。

（i）周辺単純支持の場合：第 8 図に，周辺単純支持の 場合において，計測点数が荷重履歴の同定精度に及ほす影 響を示す。この結果より，9点に計測点数を減少させて も，反復法を用いることで精度良い同定が可能となること がわかる、ここで，第 9 図に，周辺単純支持の場合の 9 点 計測における荷重履歴の同定結果を示す，反復法を用いる ことにより荷重履歴のピーク值はほほ正解が得られてお り，この結果からも反復法の有効性がわかる。 


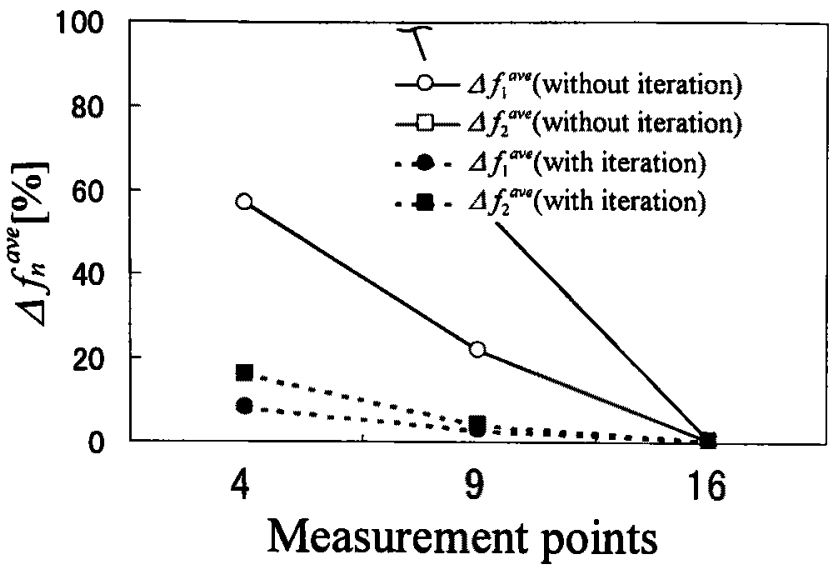

第 12 図 隇少させた計測点数が荷重履歴の同定精度に及滛す 影䈏（2 点衝擊荷重，周辺単純支持）

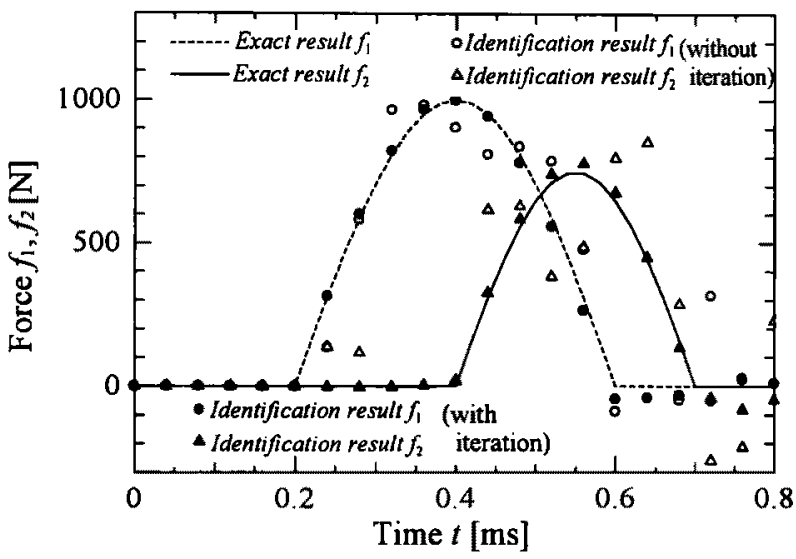

第 13 図 2 点衝擊荷重の荷重履歴同定結果（周辺单純支持， 計測点数: 9 点)

（ii）周辺固定支持の場合：第 10 図に，周辺固定支持の 場合において, 計測点数が荷重履歴の同定精度に及沽す影 響を示す。この結果より，16点に計測点数を減少させて も，反復法を用いることにより， $\Delta f_{1}^{\text {ave }}$ が $5 \%$ 程度以下の 同定が可能となることがわかる。ここで，第 11 図には， 周辺固定支持の場合の 16 点計測におりる荷重履歷の同定 結果を示す。この図から，反復法により荷重履歷ピーク值 付近で同定精度の改善がなされていることがわかる。

3.2 .22 点衝撃荷重 ここでは，2 点衝撃荷重の場合に ついて荷重履歴同定を行った。

(i) 周辺単純支持の場合：第 12 図に，周辺単純支持の 場合において, 計測点数が荷重履歴の同定精度に及经寸影 響を示す。この結果より，9点に計測点数を隇少させて も，反復法を用いることにより，荷重 1 , 荷重 2 とも大幅 な同定精度改善がなされることがわかる。ここで，第 13 図に，周辺単純支持の場合の 9 点計測における荷重履歴の 同定結果を示す，反復法を用いない場合は，同定結果に正 解值と大きなずれが生じているが，反復法を用いた場合 は，同定誤差が補正され，荷重履歷は活ほ正解値が得られ ることがわかる。

（ii）周辺固定支持の場合：第 14 図に，周辺固定支持の 場合において, 計測点数が荷重履歴の同定精度に及结寸影

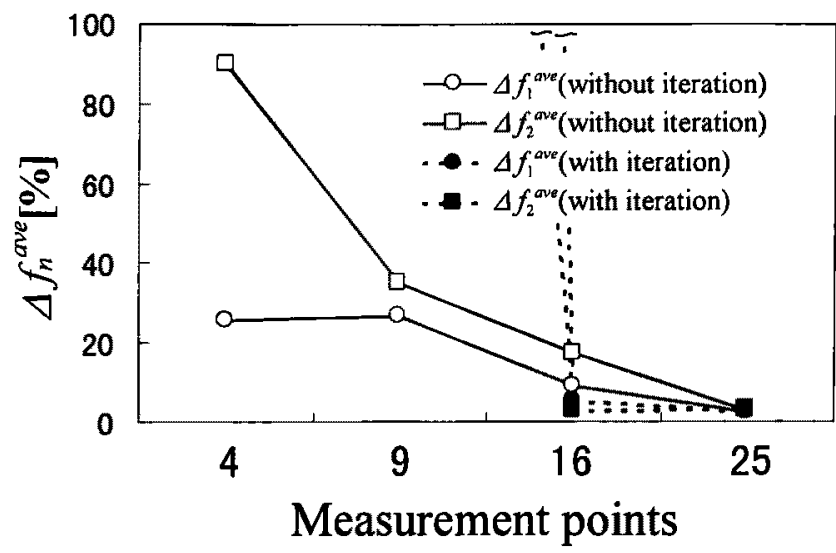

第 14 図隇少させた計測点数が荷重履歴の同定精度に及ほすす 影響（2 点衝擊荷重, 周辺固定支持)

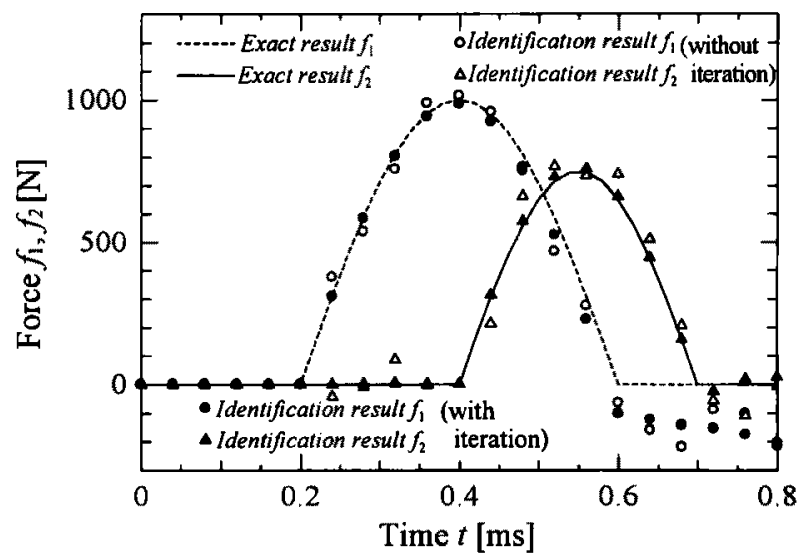

第 15 図 2 点衝擊荷重の荷重履歴同定結果（周辺固定支持， 計測点数: 16 点)

響を示す。この結果より，16 点に計測点数を減少させて も，反復法を用いることで，精度良い同定が可能となるこ とがわかる、ここで，第 15 図に，周辺固定支持の場合の 16 点計測における荷重履歴の同定結果を示す．この場合 も，反復法の使用により同定精度が向上しており，その有 効性がわかる.

以上より，反復法は，1 点衝撃荷重， 2 点衝擊荷重およ び境界条件を問わず有効であり，反復法を用いることによ り計測点数を減少させた場合においても精度良い同定が可 能となることが示された．

\section{4. 結}

\section{言}

本研究では，周辺単純支持および周辺固定支持值交異方 性積層板上の複数点に作用する衝撃荷重の荷重履歷同定方 法を確立した。また，各境界条件において計測点数が同定 精度に及浑す影響について検討した。ささらに，同定すると きに反復法を用いることにより，加速度計測点数を減少さ せた場合に扔ける同定精度の改善について検討した。

数值計算例では, 周辺単純支持㧍よび周辺固定支持の直 交異方性積層板を対象とし, 点衝撃荷重の荷重位置が既知 の場合について荷重履歴の同定を行った．本研究で対象と した 1 点， 2 点衝擊荷重については，周辺単純支持の場合 
は 16 点, 周辺固定支持の場合は 25 点の計測点数を用いれ ば精度良い同定が可能であった。この結果, 本同定方法 は，積層板の境界条件が周辺固定支持の場合に対しても有 効であること，また，境界条件によって精度良い同定を行 うために最低限要求される計測点数は異なることがわかっ た。

次に，荷重履歴同定に反復法を適用した場合について検 討した，反復法により，1点，2点衝撃荷重を問わず，周 辺単純支持の場合は 9 点に，周辺固定支持の場合は 16 点 に計測点数を減少させても精度良い同定が可能となった。 この結果，反復法は計測点数を減少させた場合における同 定精度改善に有効であることが示された。

\section{参 考 文 献}

1) Doyle, J.F.: An Experimental Method for Determining the Dynamic Contact Law, Exp. Mech., 24 (1984), pp. 10-16.

2) Doyle, J.F.: Further Developments in Determining the Dynamic Contact Law, Exp. Mech., 24 (1984), pp. 265-270.

3) Zhu, J. and Lu, Z.: A Time Domain Method for Identifying Dynamic Loads on Continuous Systems, J. Sound Vib., 148 (1991), pp. 137-146.

4) Busby, H.R. and Trujillo, D.M.: Solution of an Inverse
Dynamics Problem Using an Eigenvalue Reduction Technique, Comput. Struct., 25 (1987), pp. 109-117.

5) Hollandsworth, P.E. and Busby, H. R. : Impact Force Identification Using the General Inverse Technique, Int. J. Impact Eng., 8 (1989), pp. 315-322.

6）井上裕嗣，渡辺隆一，渋谷寿一，小泉 堯：逆たたみ込み法による 衝繁力の測定, 非破濖検査, 37 (1988), pp. 337-342.

7）放生明廣，茶谷明義，上村文人：畳み込み積分による衝擊力推定 法, 機論, 55, A (1989), pp. 477-482.

8) Yen, C. S. and $\mathrm{Wu}, \mathrm{E}$. : On the Inverse Problem of Rectangular Plates Subjected to Elastic Impact, Part I : Method Development and Numerical Verification, Trans. ASME, J. Appl. Mech., 62 (1995), pp. 692-698.

9) Yen, C. S. and Wu, E.: On the Inverse Problem of Rectangular Plates Subjected to Elastic Impact, Part II : Experimental Verification and Further Applications, Trans. ASME, J. Appl. Mech., 62 (1995), pp. 699-705.

10) Jones, R. T., Sirkis, J.S. and Friebele, E. J. : Detection of Impact Location and Magnitude for Isotropic Plates Using Neural Networks, J. Int. Mater. System Struct., 7 (1997), pp. 90-99.

11）佐藤正喜, 小野㟝徹, 関根英樹, 福永久雄 : 直交異方性積層板にお ける複数衝撃荷重の簡便な同定方法の提案, 機墖, 64，A (1998), pp. 2677-2685.

12) Fukunaga, H., Sekine, H. and Okada, K. : Stiffness Identification of Symmetrically Laminated Plates Using Bending Deflection, Mater. Sci. Research Int., 2 (1996), pp. 9398. 